This item was submitted to Loughborough's Research Repository by the author.

Items in Figshare are protected by copyright, with all rights reserved, unless otherwise indicated.

\title{
Reimagining leadership in sport management: lessons from the social construction of leadership
}

PLEASE CITE THE PUBLISHED VERSION

https://doi.org/10.1123/jsm.2017-0210

\section{PUBLISHER}

(c) Human Kinetics

\section{VERSION}

AM (Accepted Manuscript)

\section{PUBLISHER STATEMENT}

This work is made available according to the conditions of the Creative Commons Attribution-NonCommercialNoDerivatives 4.0 International (CC BY-NC-ND 4.0) licence. Full details of this licence are available at: https://creativecommons.org/licenses/by-nc-nd/4.0/

\section{LICENCE}

CC BY-NC-ND 4.0

\section{REPOSITORY RECORD}

Billsberry, Jon, Jacqueline Mueller, James Skinner, Steve Swanson, Ben Corbett, and Lesley Ferkins. 2018. "Reimagining Leadership in Sport Management: Lessons from the Social Construction of Leadership". Loughborough University. https://hdl.handle.net/2134/26504. 


\title{
Reimagining Leadership in Sport Management: Lessons from the Social Construction of Leadership
}

\begin{abstract}
Conventional approaches to leadership in sport management regard leadership as a leader-centric phenomenon. Recent advances in the generic leadership literature have highlighted the way that people construct their own understanding of leadership and shown that these influence their assessment and responses to people they regard as leaders. This observer-centric perspective is collectively known as the social construction of leadership. In this conceptual paper, we demonstrate how this emerging theoretical approach can reframe and invigorate our understanding of leadership in sport management. We explore the research implications of this new approach, reflect on what this might mean for teaching, and discuss the practical ramifications for leadership in sport management that might flow from the adoption of this approach.
\end{abstract}

\section{Keywords}

Leadership, management, social construction, implicit leadership theory, sport management, sport business management 


\section{Reimagining Leadership in Sport Management: Lessons from the Social Construction of Leadership}

As a transdisciplinary topic, leadership has relevance across many contexts, but there are very few where it is more relevant than in sport management. Role assigned leaders such as team captains, team managers, CEOs, Chairpersons, and Presidents of sport organizations all attract considerable attention, and the effectiveness of their leadership is commonly viewed as the primary cause of success or failure (Meindl, Ehrlich, \& Dukerich, 1985; Schyns, Gilmore \& Dietz, 2016). However, insights in the generic leadership literature challenge the notion that leadership is a quality of leaders and that the success or failure of leaders is not a matter of their 'actual' performance, but instead depends on how others and society views it (Barker, 2001, 2002; Grint, 2000; Meindl, 1995). This alternative observer-centric approach is known as the social construction of leadership (Fairhurst \& Grant, 2010; Meindl, 1995; Schyns \& Schilling, 2011).

Given the importance of leadership to this context, it is surprising that the discussion of leadership in sport management has a traditional air centered on leadercentric theories and has largely ignored emerging leadership ideas such as observercentric perspectives (Welty Peachey, Damon, Zhou, \& Burton, 2015). As we shall show, ideas associated with the social construction of leadership help explain the criteria by which sport leaders are assessed, help us understand what players, fans, and support and managerial staff seek in their leaders, and provide a guidance for leadership development. 
In short, the socially-constructed approach to leadership has the capacity to create new research agendas, new curricula for leadership development, and new lessons for leadership practice in sport management (Fairhurst \& Grant, 2010).

This paper makes a contribution to the sport management leadership literature by introducing and applying the notion of the social construction of leadership (e.g., Fairhurst \& Grant, 2010; Grint, 1997, 2000, 2005; Grint \& Jackson, 2010, Meindl, 1995; Schyns \& Meindl, 2005). We begin by reviewing leadership research in sport management by drawing out its main findings and philosophical stance. In the second section of this paper, we explain the socially-constructed approach to leadership, noting its key features and underpinning epistemology. Then, we discuss the implications of applying this relatively new approach to leadership in sport management from a variety of different perspectives. To reiterate, the main purpose of this paper is to advocate for the increased adoption of the social construction approach to leadership in the discipline of sport management and to explore the research, teaching, and sport management practice implications that flow from this exercise.

\section{Leadership Research in a Sport Management Context}

Leadership research in sport management has continually lagged behind the generic leadership literature (Kihl, Leberman, \& Schull, 2010). This is surprising given the centrality of leadership in all forms of sport (e.g., 'on-field', 'off-field', non-profit, forprofit, etc.). Of this body of knowledge, leadership research within sport management has been largely drawn from North American, European and Australasian contexts, and has typically concentrated on individual or formal leader characteristics or behaviors (Kihl et al., 2010; Welty Peachy et al., 2015). In this environment, there is an emphasis on the 
CEOs of organizations, board chairs, managers, and coaches. In fact, the leader tends to be exalted, the center of attention, and their charisma commonly attributed to success (Day, Fleenor, Atwater, Sturm, \& McKee, 2014; Elgar, 2016; Ferkins, Shilbury, \& McDonald, 2009; Meindl, 1995; Offermann, Kennedy, \& Wirtz, 1994; Welty Peachey, et al., 2015; Swanson \& Kent, 2014; Wood, 2005).

The emphasis on coaches, in particular, has created early foundational knowledge in leadership for sport management (Chelladurai, 1980; Fletcher \& Arnold, 2011; Jowett \& Chaundy, 2004; Kellett, 1999; Sullivan, Paquette, Holt, \& Bloom, 2012). Chelladurai's (1980) seminal work on this helped to explain coaching behavior and leadership styles. Based on a contingency model of leadership, he developed a Multidimensional Model of Leadership specific to the sport context based on the combination of situational, leader, and follower characteristics to explain how leaders should behave. In parallel, Chelladurai and Saleh's (1980) Leadership Scale for Sports (LSS) also established dimensions of leader behavior by capturing six key leadership styles. Later, Kellett (1999) explored the relationship between management and leadership by interviewing Australian Football League professional head coaches. An emphasis on the leader (coach) reflected the approach taken in the generic leadership literature, which was dominated by leader-centered approaches. Curiously, however, Kellett's (1999) research uncovered how the coaches in her study did not perceive themselves as leaders. Instead, they considered that the role of the coach is to facilitate leadership amongst the athletes they work with, and to train athletes to become leaders (Kellett, 1999).

Another insightful article seemingly shaping the direction of leadership research in sport management is Welty Peachey et al's (2015) review of leadership research in sport 
management since its emergence in the 1970s. Their review highlights that before the mid-1980s, leadership research in sport management drew strongly from the mainstream leader-centric literature and the seminal studies (e.g., Fiedler, 1964, 1967; Lewin \& Lippitt, 1938; McGregor, 1960). As highlighted above, this research was largely used to establish the role of the team manager and the coach and to examine these leaders' behavior. In the mid-1980s to the mid-1990s, leadership research in sport management continued with its leader-centric perspective but shifted with the mainstream towards an emphasis on the new areas of transactional and transformational leadership (e.g., Doherty \& Danylchuk, 1996; Wallace \& Weese, 1995; Weese, 1995) and gender concerns in leadership (e.g., Defrantz, 1988; Lovett \& Lowry, 1988; Theberge, 1984).

When looking at changes in sport management leadership research since the mid1990s, Welty Peachey et al. (2015, p. 573) comment that there has been "continued development of previous themes, such as transformational leadership and gender issues and effects in leadership as the emergence of new concepts in sport management leadership research." The new concepts are issues of governance in sport management (e.g., Arnold, Fletcher, \& Molyneux, 2012; Ferkins \& Shilbury, 2012; Ferkins, Shilbury, \& McDonald, 2005; Fletcher \& Arnold, 2011; Parent, Beaupre, \& Seguin, 2009; Parent, Olver, \& Seguin, 2009; Shilbury, 2001; Shilbury, Ferkins, \& Smythe, 2013), leadermember exchange theory (e.g., Bang, 2011; Hoye, 2004), ethical leadership (e.g., Sagas \& Wigley, 2014; Staurowsky, 2014), servant leadership (Parris \& Welty Peachey, 2013; Weltey Peachey \& Burton, 2017), emotional intelligence (Schneider, 2012) and a shift away from adult-centric understandings of leadership to a focus on youth-centered understandings of leadership in a sporting context (Skinner \& Lizzio, 2011). Importantly 
for our line of argument, although these are important and valid areas of research, Welty Peachey et al's (2015) authoritative review demonstrates that leadership research in sport management has been dominated by leader-centric notions and is yet to embrace new ideas associated with the social construction of leadership in any sustained way.

To counter this, a small number of studies have sought stakeholder perspectives within leadership research in sport management. This has helped to move the focus from leader traits and behaviors by capturing the views of observers or followers (Ferkins \& Shilbury, 2015; Kihl et al., 2010; Parent, Olver \& Séguin, 2009b). In particular, Kihl et al. (2010) examined stakeholder perceptions of leadership in relation to change within intercollegiate sport. Internal and external stakeholders considered both leaders' and followers' shared perceptions of leadership. The authors were also critical of leadership research in sport management to date, stating that it "is characterized by post-positivist approaches that are permeated by quantitative designs, largely neglecting the role of context and stakeholders" (p. 241). They argue that "how stakeholders interpret the organizational context and the various relationships among leaders, superiors, peers and subordinates informs their construction of the nature of leadership and its effectiveness within specific institutional settings" (p. 242). We, too, consider that positioning leadership research within a social constructionist perspective will reveal new and insightful viewpoints of leadership for the sport management setting, just as it has offered major advancement for leadership and leadership development within other settings (Billsberry, 2016; Grint \& Jackson, 2010).

The main limitation of leadership studies within sport management is that, with the few exceptions mentioned above, they take an abiding essentialist perspective towards 
leadership. Essentialism is the notion that there is an immutable underlying 'essence' or objective truth to be discovered about leadership (Toosi \& Ambady, 2011). After more than 2000 years of leadership research that has failed to deliver an agreed definition of leadership, a dominant theory of leadership, or even a person whom everyone agrees is a leader, most mainstream leadership scholars have given up on the essentialist expedition. Instead, as we shall show, there are many practical benefits to be gained by considering leadership as a psychological phenomenon with each person holding their own definition, theory, and responses. In other words, rather than trying to discover the traits and behaviors comprising the ideal coach, which seems to be proving an impossible task, the alternative philosophy is to consider and react to what players want from their coach in terms of leadership. This is the change of perspective that the social construction approach to leadership offers.

\section{The Social Construction of Leadership}

Traditional approaches to leadership hold that leadership is a quality of leaders; their traits, their ability to bring about change and transformation, their authenticity, and their behaviors (Grint, 1997, 2005; Mello, 2003). This leader-centric approach has dominated leadership scholarship for centuries, if not millennia. Yet, despite being one of the longest standing research domains charting back to the dawn of civilization (e.g., Sun Tzu, Plato, Aristotle through Machiavelli and Von Clausewitz, to the current day), we do not even have an agreed definition of leadership (Fairhurst \& Grant, 2010; Jackson \& Parry, 2011; Stogdill, 1974), or an agreed way to teach it (Doh, 2003).

Approximately 30 years ago, a different approach to leadership began to emerge. Based on the realization that traditional leader-centric approaches were biased by 
fundamental attribution error in which people falsely over-attribute success and failure to individuals (Meindl, 1995; Meindl et al., 1985), an observer-centric approach emerged. Put simply, this new approach (also considered a paradigm) equated leadership to emotional responses such as love and beauty and argued that leadership was in the eye of the beholder (Fairhurst \& Grant, 2010; Meisel, \& Billsberry, 2009). Rather than being a quality of leaders, leadership is a perceptual evaluation of the actors that people encounter. They see and hear about some people doing things that accord with their notion of leadership and give them the label 'leader' (Harvey, 2006). Hence, leadership is an internal assessment and centered on the people observing (in its widest sense) others, and crucially it is not about leaders per se. Constructionists, therefore, deny essentialism (Toosi \& Ambady, 2011).

This approach explains several well-established problems with leader-centric perspectives on leadership. For example, as we are all different and have different interpretations of the world, it explains why people regard different people as leaders, and also why they have different reasons for thinking them to be leaders. It also explains why we cannot identify a person whom everyone agrees to be a leader. As the saying goes, 'one person's terrorist is another person's freedom fighter'. Interestingly, the social construction approach makes leadership relevant to everyone in every situation.

Leadership is not the preserve of the 'good and the great'; instead, it gives us a theoretical way to explain leadership in all strata of society.

In the world of the social constructionism, there is no objective world waiting to be discovered. Instead, there are multiple truths and realities competing for legitimacy and dominance (Fairhurst \& Grant, 2010). The 'social' in the phrase 'the social construction 
of leadership' at first seems at odds with the individualized nature of people's mental models. Grint (1997) explains that people live in a social world and in that social world there is debate about people's words and actions. Some people have more persuasive voices than others, some have greater credibility, and others have greater access to media outlets. Over time, agreement emerges on whom society regards as a leader, but it never coalesces to a singular view (Fairhurst \& Grant 2010; Grint 1997, 2005; Grint \& Jackson, 2010).

Another repercussion of the absence of an objective world (i.e., a world where leadership is not a quality of leaders, and 'leaders' do not exist as objects scattered across society), is that leadership is both an interpretive and a contestable notion (Fairhurst \& Grant, 2010; Grint, 2000). In this subjective world, the focus tends to be on how and why people differently interpret the behavior of the people they do and do not regard as leaders, looking for difference, variability, and inconsistency. There may not be objective truth to discover; instead, the goal is to understand how each person arrives at 'their' truth and how this is similar to, differs from, and is influenced by other people.

The philosophical roots of the social construction of leadership can be traced back many centuries to the work of the Irish philosopher Bishop Berkeley (1685-1753); 'esse est percipi (aut percipere)' usually translated into English as "to be is to be perceived (or to perceive)". The ontological approach that has grown from these foundations is variously called subjectivism, constructionism, or interpretivism (Sandberg, 2001). It contrasts to the notion that there is an external reality that is believed to exist, which is termed objectivism. The objectivism-subjectivism division is the primary one in ontology (Blaikie, 2007; MacLeod, 2015). Is there an objective reality waiting to be discovered, or 
is meaning created in our own heads? The socially-constructed approach to leadership takes the second of these approaches, and is based on the view that leadership is created in the minds of people as they react to the behavior of others of whom they become aware.

While an explanation of the deeper ontological underpinnings is beyond the scope of this paper, the social construction of leadership (a relatively new approach in the field of leadership), is built on well-established and legitimate philosophical foundations. As is typical in many fields of study, even in a relatively young field such as the social construction of leadership, a variety of approaches have emerged (Fairhurst \& Grant, 2010). Sandberg (2001) has usefully summarized ontological and epistemological foundations and notes that four qualities are common across the paradigm. First, he argues that they share a relational ontology that rejects the notion of a dualistic ontology in which subject (i.e., the observer) and object (i.e., the leader) are treated as separate and independent entities. Instead, reality is constructed as a lived experience and the subject and object cannot be separated. Following on from his first point, secondly, he rejects an objectivistic epistemology and asserts that reality is socially-constructed. Third, he argues that socially-constructed approaches to leadership share a social epistemology in which "our descriptions of reality are not objective but are socially produced" (Sandberg, 2001, p. 108). Fourth, this social production is created by a socially-constructed language rather than a language that is a mirror of objective reality. Our descriptions of reality "are always colored by our specific historical, cultural and linguistic understanding of reality ... [thus] reality is socially constructed by continuous negotiation between people about what their reality is" (Sandberg, 2001, p. 108). 
An interesting aspect of the socially-constructed approach to leadership is that the most important leadership theories are the lay theories inside people's heads (Epitropaki, Sy, Martin, Tram-Quon, \& Topakas, 2013). These are the leadership theories that determine how people interpret the various stimuli (e.g., observations of behavior, conversations with others about important events, and listening or watching reports about influential people) they receive. They also shape their assessment of whom they do and do not consider a leader, and, crucially, shape the behaviors they adopt when they want to be seen as a leader by others, thereby giving the approach a praxis as well as a theory perspective (Fairhurst \& Grant, 2010; Marshak \& Grant, 2008). This “naïve psychology” (Calder, 1977, p. 202) relies on attribution theory (Kelley \& Michela, 1980; Martinko, Harvey, Douglas, 2007; Meindl, 1995) to explain the sensemaking processes that people employ in relation to leadership. By placing assessments of leadership inside people's heads, the approach asserts the importance of people's own mental models of leadership (Billsberry, 2016; Schyns, Kiefer, Kerschreiter, \& Tymon, 2011). These are known as implicit leadership theories (ILTs). ILTs form over people's lives based on their experience and interaction with the social world (Schyns et al., 2011). They explain people's behavior and reactions to others within a leadership context (Kenney, SchwartzKenney, \& Blascovich, 1996; Schyns \& Schilling, 2011). Interacting with the various stimuli they receive, ILTs determine who someone thinks is a leader, why, and their reactions to them.

Surfacing people's ILTs has largely taken one of two approaches. Either researchers have asked their respondents to focus on their ideal or prototypical leader, or, they have been asked to consider leaders more generally. In the first stream of research, 
the goal is to explore prototypical leaders' behaviors and examine the impact on followers (Schyns \& Meindl, 2005). For example, Phillips and Lord (1986) and Rush, Phillips, and Lord (1981) looked at how perceptions of leaders were altered by information about their performance. More recently, for example, Trichas, Schyns, Lord, and Hall (2016) studied the impact of facial impressions on people's perceptions of leadership and ILTs. They found, perhaps not surprisingly, that happy expressions resulted in higher leadership ratings than nervous expressions. Notable studies in the second stream of research include Offerman, Kennedy and Wirtz (1994, p. 43) who discovered "eight distinct factors of ILTs ('sensitivity', 'dedication,' 'tyranny,' 'charisma,' 'attractiveness,' 'masculinity,' 'intelligence,' and 'strength') that remain relatively stable across both perceiver sex and stimuli." They noted that ILTs appear to vary in systemic ways, suggesting that it is important to discover not just their content but their structure and dynamic nature as well. Bridging between the two types of ILT research, Schyns and Schilling (2011, p. 144) asked 76 people to "name six attributes of a leader in general and to rate these characteristics and the leader in general on effectiveness." Their analysis showed that when people were directed towards 'leaders in general' rather than 'ideal leaders', the content of their ILTs contained both positive (e.g., 'charismatic,' 'team player,' and 'communicative') and negative (e.g., 'unpleasant,' 'weak,' and 'tyrannical') attributes.

Just as people have naïve or lay theories related to leadership, they also have implicit theories about followership (Bligh, Kohles, \& Pillai, 2011; Foti, Hansbrough, Epitropaki, \& Coyle, 2017; Junker, Stegmann, Braun, \& Van Dick, 2016; Sy, 2010; UhlBien, Riggio, Lowe, \& Carsten, 2014). Implicit followership theories (IFTs) are formally 
defined as “individuals' personal assumptions about the traits and behaviors that characterize followers" (Sy, 2010: p. 74). As such, IFTs operate as the sensemaking process through which individuals "interpret, understand, and respond to follower behaviors" (Sy, 2010, p. 74). IFTs are a benchmark against which people compare followers' behaviors and this influences their actions towards them (Lord \& Maher, 1993). To date, IFT research has tended to focus on prototypical and ideal followers rather than followers in general (Foti et al., 2017). Sy’s (2010) original work on IFTs differentiated between two types of IFTs; those of the leader (LIFT) and those of the follower (FIFT). LIFTs contain leaders' personal assumptions about the traits and behaviors that characterize followers and have been shown to be positively correlated with followers' performance (Whiteley, Sy, \& Johnson, 2012) and followers' affect (Epitropaki et al., 2013; Kruse \& Sy, 2011). Much less is known about FIFTs, followers' personal assumptions about the qualities and behavior of followers (Uhl-Bien et al., 2012), but seem an important avenue for future research because conceptually they influence followers' behavioral reactions to those they regard as leaders.

The social construction of leadership also has a role to play in leader and leadership development (Iles \& Preece, 2006). In particular, the approach orientates development towards improvement of self- and social-awareness, and in particular towards an identification of ILTs and how those being developed come across to others (Schyns et al., 2011). The fundamental idea is that as people hoping to be seen as leaders improve their self-awareness and begin to understand the nature of their ILTs, they discover how their own unconscious processes have been shaping their behavior, which helps them 
better appreciate how the image they project is perceived by others (Billsberry, 2016; Schyns et al., 2011).

One of the most interesting consequences of the socially-constructed approach to leadership is that it opens up the concept of leadership. In this approach, leadership might be witnessed anytime, anywhere, and in anyone (Ospina \& Foldy, 2010). It is all a matter of perception, and it is equally likely to be observed by a supervisor witnessing the actions of his or her cleaner, as it is a citizen watching news reports of the Prime Minister, the Pope, or the coach of the New England Patriots. This approach, which also challenges the notion of leadership being restricted to assigned roles in a hierarchy (Baruch, 1998), has a democratizing orientation and makes leadership relevant across levels (i.e., micro, meso, and macro; Epitropaki, Kark, Mainemelis, \& Lord, 2017; Pillai \& Meindl, 1998; Tee, Paulsen, \& Ashkanasy, 2013) and circumstances (Ospina \& Foldy, 2010).

We should also explain why we have adopted the term 'observer-centric' rather than the term more commonly found in the literature, 'follower-centric', to describe the alternative perspective to leader-centric approaches. The answer is quite simple. Many people will receive sensory inputs on a particular person. Some will interpret these stimuli through their ILTs and arrive at the conclusion that the person is a leader in their eyes, making them followers. Others will interpret these stimuli differently and not come to conclusion that the person is a leader. Hence, followers is a sub-set of all those who have observed the person they believe to be a leader. Calling the approach 'observercentric' appreciates that some individuals observe the people that others believe are leaders, but do not think they are leaders themselves. Hence, the label 'observer-centric' 
adds clarity, is a more encompassing term, and does not deny the presence and importance of deniers.

To date, the social construction approach to leadership has mainly been employed as a critical adjunct to traditional leader-centric views on leadership (Grint \& Jackson, 2010). It highlights severe weaknesses in mainstream theories such as the aforementioned difficulties defining leadership and identifying people we all agree are leaders. However, it is our assertion that, in addition to being a critical theory, the approach has a key role to play in real-world practical leadership development.

\section{Implications for Leadership Research in Sport Management}

As demonstrated earlier, most leadership research in sport management has taken a leader-centric approach and focused on individual or formal leader characteristics and behaviors (Kihl et al, 2010; Welty Peachy et al., 2015). There has been an emphasis on studying the senior people with assigned roles in sport organizations and the factors contributing to their success. The socially-constructed approach to leadership does not deny such empirical work, but it would offer reinterpretations of the findings. For example, in the paper in which Chelladurai and Saleh (1980) developed their much-used LSS, the authors discuss their findings, "Training and Instruction, includes 13 items. It reflects one of the most important functions of a coach-to improve the performance level of the athlete. (p. 41) ... The factor Democratic Behavior is composed of nine items. It reflects the extent to which the coach permits participation by the athletes in decision making (p. 41)" ... These dimensions are consistent with the path-goal theory of leadership (House \& Dessler, 1974), they are conceptually distinct categories of coaching behavior, and each of the dimensions is relatively stable (p. 43)". The natural tendency, 
as illustrated by the authors' own words, is to take the data generated by the questionnaire and relate it to qualities of the sport leaders; that is, it assumes that the data relates to leaders. However, when we examine the LSS in detail we see that the instructions to respondents reads, "Each item in the LSS was preceded with the phrase, 'The coach should...', and five response categories were provided: always, often, occasionally, seldom, and never.” (p. 36). In so doing, the questionnaire is generating data on participants' perceptions of leaders. This is a subtle, but important observation; it is about how people view coaches, not a study of the coaches themselves. So, we might use the questionnaire to learn about whether people believe a coach's role is to improve the performance of athletes and whether they believe that coaches should permit athletes to participate in decision making, but not as an objective assessment of the coaches.

This problem is not confined to quantitative studies of leadership in sport. There are examples of qualitative studies that employ interviews and similar instruments to gather data that are also written-up in a manner that implies that something has been learned about leadership, rather than about the perceptions of the interviewees on leadership matters. For example, Fletcher and Arnold (2011) interviewed 13 national performance directors of Olympic sports in the UK to surface best practice in leading and managing elite sport. After meticulous care reporting the comments of their interviewees in their results section indicating that these comments were opinions, Fletcher and Arnold (2011) concluded with what we consider a leader-centric statement, "The data reported here supports this assertion by elucidating best practice for leading and managing teams in preparation for Olympic competition. More specifically, the findings highlight the multifaceted nature of orchestrating elite performance involving the development of a 
vision, the management of operations, the leadership of people, and the creation of a culture" (p. 234). Their conclusion is that their interviewees' (i.e., the leaders') comments are best practice in leading elite sport, rather than their opinions about what they think represent best practice in this field. This subtle distinction demonstrates the seductiveness of leader-centric language and its power to distort meaning.

The socially-constructed approach to leadership thus reminds us that data such as those illustrated above represents opinions and has a normative quality. Accordingly, it prompts a more accurate reading of research data and changes the way we draw conclusions from such research findings. This is an important reminder in a world that is increasingly driven by image, impressions, and the media and knowing how people perceive leaders is important (Smith \& Stewart, 2010). The first research implication from the social construction approach is, therefore, that rather than examine the factors influencing leadership, research aligned to this paradigm examines how observers attribute leadership. The meaning of leadership rests within the observer and research would consider the various factors influencing observers' perceptions of leaders. What do people observe? How do they balance and evaluate the various sensory stimuli? What do they regard as important? Who are the more 'powerful voices' (Grint, 1997) influencing their leadership assessments?

Turning attention to those witnessing leaders, the socially-constructed approach therefore places ILTs at the fore of leadership research in sport management. These are the cognitive schemas explaining people's lay theories of leadership, which guide their sensemaking processes when perceiving and reacting to leaders. One factor likely to influence the perceived success or failure of a leader is whether they are seen behaving in 
ways that accord with the ILTs of the people in that environment. Hence, surfacing the relevant ILTs in sport organizations would appear to be a valuable activity that will inform people of the types of behavior that will be viewed as leadership. An interesting aspect of leadership in sport organizations is that there are very different subcultures in different parts of the organization; typically, the playing teams, the corporate boardroom, the administrative back office, the volunteers, the game day employees, and the fans and supporters. To what extent do the ILTs in these environments mesh into one consistent approach to leadership? Can different ILTs coexist or are they antagonistic? In terms of functioning and performance, it may be valuable to look at the homogeneity of ILTs within different parts of the sport organization. For example, within a playing team, key research questions that it would be important to investigate include whether there is agreement of what constitutes leadership in that environment and whether anyone, especially the appointed leader, is seen displaying those behaviors by the members of the team.

More clarity is needed in how the social construction approach relates to other established concepts of leadership. As one example, a tension appears to exist between an observer-centric approach and the notion that leaders should be authentic in their efforts to influence followers. Specifically, core dimensions of authentic leadership focus on self-awareness, transparency of self, and self-regulation (Walumbwa, Avolio, Gardner, Wernsing, \& Peterson, 2008). This suggests a leader's perspective of self is paramount to considering the views of others. However, when considering this apparent inconsistency, we must also recognize that measures developed to assess such theoretical positions are done so by asking others (i.e., observers) to describe a leader they consider to be 
authentic. Such an approach therefore suggests that when leader-centric views are considered in a leadership study (and measured via perceptions of the leader), ILTs are implicitly incorporated into the focal leadership concept. Further consideration of how various leadership perspectives are dependent upon social construction would complement these more established views by recognizing the other side of the same coin.

Although these ILT-related questions assert themselves, one of the most pressing challenges in this field is finding efficient ways to surface and then compare and combine the mental models. A range of techniques have been employed ranging from direct requests for information about people's ILTs and IFTs (e.g., Engle \& Lord, 1997; Lord et al., 1984; Whiteley et al., 2012) to more indirect methods (e.g., Billsberry, 2016; Schyns et al., 2011). Engle and Lord (1997), for example, asked people to rate the prototypicality of several traits and behaviors associated with leadership. Whiteley et al. (2012) created a short questionnaire with items taken from Sy (2010), which the respondents used to rate followers. Researchers who believe that ILTs are not consciously held usually use laborious projective and qualitative techniques requiring skillful facilitation and interpretation to surface ILTs (Schyns et al., 2011; Schyns \& Meindl, 2005). Typical approaches include drawing (Ayman-Nolley \& Ayman, 2005; Schyns et al., 2011), and cognitive mapping and word association (Billsberry, 2016). These methods may have limited face validity in a sport organization context, so a fruitful avenue of research would be the development of simpler and more conventional methods.

There are examples of developing lists of constructs thought to be part of ILTs and IFTs (e.g., Offerman et al., 1994; Schyns \& Schilling, 2011; Sy, 2010), but these do not constitute a formal attempt to create a set of commonly-held qualities. Such development 
is useful in the same way that the development of the Big Five personality traits have aided personality research (Barrick \& Mount, 1991; De Hoogh, Den Hartog, \& Koopman, 2005; Judge, Bono, Ilies, \& Gerhardt, 2002). The Big Five personality traits are commonly misunderstood to represent the fundamental building blocks of personality. This was not the intention for which they were designed (Barrick \& Mount, 1991). Instead, they are five dimensions of personality that have been shown to be relevant in most situations (Barrick \& Mount, 1991). As such, they provide a structure around which comparative personality research can be done, provide a handy shorthand, and sidestep the problem of the idiosyncrasy of personality and individual difference. The same is likely to be true with ILTs. Every person's ILT is different, as they have had different exposure and experiences during their lives (Lord, 2005), seemingly making their application too complex. However, if common pillars of ILTs can be discovered, it would make research, teaching, and practical applications of ILTs in the sport management context and beyond, simpler and more achievable (Eden \& Leviatan, 1975).

Identifying these pillars may not be as difficult as first imagined, as the findings of empirical leadership trait studies appear to surface the similar aspects of people's perceptions of leadership. For example, Stogdill (1948), Mann (1959), and Lord et al. (1986) included "intelligence" in their lists of traits, and other traits such as "integrity", "confidence", "dominance", "initiative", "drive", and "vision" commonly appear in these and other lists of leadership traits (e.g., Bass, 1990; Daft, 1999; Fitzpatrick \& Locke, 1991; Hogan, Curphy, \& Hogan, 1994; House \& Aditya, 1997; Judge et al., 2002; Lord et al., 1986; Mann, 1959; Nichols, 2015; Stogdill, 1948, 1974; Yukl, 1998; Yukl \& Van Fleet, 1992). As mentioned earlier, as these leadership trait studies tend to have a 
socially-constructed design, they provide a useful starting point for work seeking to establish elements of ILTs that are common across various situations and contexts.

\section{Implications for Teaching Leadership in Sport Management}

Before discussing those contributions that have explored a socially-constructed approach to teaching leadership, it is important to acknowledge that many existing teaching techniques in sport management might be used within a social construction approach. Any teaching method in leadership development that denies a leader-centric approach and adopts an observer-centric one would align itself with social construction. Counter-intuitively, it seems that any existing teaching or development technique might be useful; it all depends on how the instructor or developer conceptualizes leadership. Hence, when looking at the teaching implications stemming from social construction, we are rarely looking at individual techniques, but more at the perspective on leadership that the sport management teacher adopts.

Interestingly, Billsberry (2016) argues that when instructors take a sociallyconstructed approach to leadership, it constitutes a threshold concept. A threshold concept is a fundamental idea in a discipline that, once learned, cannot be forgotten (Wright \& Gilmore, 2011). And once acquired, this idea transforms students' understanding of a topic and opens up further and higher levels of study (Meyer \& Land, 2005). They are conceptual 'gateways' or 'portals' that must be negotiated to arrive at important new understandings (Meyer, 2008). Meyer and Land (2005) describe threshold concepts as troublesome ideas that are central to the discipline and once mastered mark the transition from a basic to an advanced understanding of the subject. Regarding the social construction of leadership as a threshold concept would mean that once 
internalized, the approach would supplant leader-centric notions of leadership, and thereby help students make better sense of previous leadership findings that are rooted in leader-centric theories, as we demonstrated earlier with our reinterpretation of Chelladurai and Saleh (1980). If we consider that the social construction approach to leadership in sport management is a threshold concept, there are some important implications for teaching the subject.

Perhaps the most challenging teaching implication is the change of emphasis that instructors will have to take towards the subject. Not only are leader-centric ideas deeply ingrained in students, they are perhaps even more deeply ingrained in most leadership instructors; these are people who have been studying, researching, publishing, and training in leader-centric ways throughout their careers. In effect, we are advocating a paradigm shift in this subject, and such a step is always challenging, uncomfortable, and met with resistance (Anderson \& Funnell, 2005; Kuhn, 1970). Nevertheless, we are increasingly thinking in these terms. In our own teaching using methods rooted in this new approach, we are seeing students walk away from our observer-centric teaching with an empowered understanding of leadership, one that helps them understand and rise to their leadership challenges. Previously leader-centric modules produced, at best, curiosity, engagement, and a few insights, but seemingly little of lasting usefulness.

Socially-constructed approaches are likely to begin with periods of unlearning to address natural preconceived notions that leadership is a quality of leaders (Billsberry, 2016). There are many ways of doing this. Billsberry (2013), for example, challenges his students to find a person whom everyone agrees is a leader and to find a universally accepted definition of leadership. From these impossible tasks, he starts a discussion 
about the nature of leadership in which the observers' role is paramount. After such unlearning, instructors will need to explain the socially-constructed approach. In our own teaching, we have found the following material useful in explaining the perspective. The film, Life of Brian (Jones, Chapman, Cleese, Gilliam, Idle, \& Palin, 1979), contains a protagonist who is palpably not a leader. Everyone else wants to believe he is one and see him as someone who can relieve them of their drudgery, torment, and oppressed state. This is a powerful example of leadership being an observer-centric phenomenon. We have also used the paintings of Jackson Pollock to illustrate that beauty is in the eye of the beholder and whilst people may have extremely contrasting views on the nature of his work, the 'variable' is the person looking at the paintings, not the paintings themselves. And an analysis of changing perceptions of leading sports people can demonstrate that our changing views on someone often reflect increased knowledge about them, rather than a change in the person. For example, people's perceptions of Tiger Woods as a leader changed before and after his alleged indiscretions even though the man had not; it's all a matter of the observers' perceptions. Such exercises can be supplemented by asking students to perform a 360-degree assessment of their leadership. This approach reinforces the importance of the observers' role in leadership assessment (Billsberry, 2016). In addition, the teaching might explain the social construction of leadership perspective and discuss its philosophical underpinnings to create reassurance that although this approach is undoing a lifetime's understanding of leadership, it has rigorous theoretical and philosophical roots.

As a threshold concept, once students understand the approach, it opens up new ways to tackle the subject (Wright \& Gilmore, 2013). Elements of the curriculum that 
naturally flow from a socially-constructed approach include sensation and perception (i.e., the leadership stimuli that observers receive), implicit leadership theories (i.e., how observers make sense of these sensory inputs in leadership terms), and impression management (i.e., how to influence how observers perceive you). In addition, natural extensions include persuasion and argument, self-awareness, emotional intelligence, critical thinking, networking, influence, and a range of communication and interpersonal skills. These topics all focus on the interaction of people and how they might influence perceptions of each other (Billsberry, 2013). Interestingly, they do not include the large range of leadership theories that traditionally have occupied much of the content of leadership textbooks. We would, however, based on our own experience, suggest that it is useful showing how some of the findings of the more highly cited theories might be reinterpreted from the socially-constructed perspective. This is particularly important with trait theory, as this is the natural and most dominant leadership theory (Northouse, 2015) and a re-examination of trait studies demonstrates that the vast majority are, in fact, social construction studies in that respondents were asked to say what traits they see, value, or equate with leadership in people they regard as leaders (Lord, De Vader, \& Alliger, 1986). This insight also reinforces the social construction perspective and gives students more confidence in it.

Integrating a social construction approach to leadership education should provide students with a more complete perspective on the subject. Whilst more traditional approaches relating to traits, styles, and behaviors are still necessary components of leadership teaching, the inclusion of an observer-centric perspective places the emphasis on how these elements are actually perceived by observers. Although leader-centric 
approaches include the assumption that optimal leadership characteristics and behaviors are present for successful leaders, the social construction approach provides for a more critical view that this is the case only if these leadership characteristics and behaviors are considered optimal by those who might be led. One implication for teaching is that this perspective can help supplement topics such as charismatic leadership (e.g., Conger \& Kanungo, 1989), where it is noted that positive qualities of a so-called leader depend significantly on the eye of the beholder. In sport management classrooms, this should be especially relevant to discussions on how managers need to understand the views of their employees (and, in many contexts, sport volunteers) to maximise the effectiveness of their respective leadership attributes and styles.

\section{Implications for Sport Management Practice}

Finally, the social construction of leadership has implications for practice.

Obviously, it highlights a new agenda for leadership development, as discussed earlier. But more than this, the relevance of the socially-constructed approach to leadership explains why people who have proven themselves effective in one role cannot guarantee success as a leader in subsequent roles. In new places, people will have different views of what constitutes leadership. And these different views are likely to mean a fresh and probably different evaluation of the newcomer. The approach highlights that leadership success in one arena does not necessarily mean success in a new arena. It also explains how leadership can be enacted informally, beyond the formally assigned position (e.g., CEO, chairperson, manager, or coach), which has been the focus of much leadership research in sport management to date (Welty Peachy et al., 2015). 
People in the sport sector are already keenly aware of the importance of impression management (Smith \& Stewart, 2010). With press conferences before and after games, media coverage of aspects such as league design, player payments, and ongoing scrutiny of individual players as well as systemic issues such as corruption, few industries are in the public eye so frequently. This new perspective on leadership underlines the importance of these skills and highlights the importance of 'reading' the audience. What are their expectations of leaders? What will they regard as leadership? Are people in leadership roles expected to behave differently to other people in these environments?

This new approach offers encouragement to those seeking to contribute to leadership in sport management. Theoretically, it is possible for anyone in any environment to be seen as a leader; they 'simply' need to be seen doing the things the observers regard as leadership (Grint, 1999). One of the discussions that persisted throughout the 2016-2017 English Premier League professional football season was the future of long-serving Arsenal Football Club manager, Arsene Wenger. His contract was due to end at the end of the season and there was considerable uncertainty about whether it would, or should, be renewed. He had refused to comment and this gave rise to a lot of speculation and uncertainty. At the end of the first league season in which Arsenal had not finished in the Top 4 and thereby qualify for the following season's Champions League under Arsene Wenger, the BBC interviewed him.

I believe since January we have played in a very difficult environment for different reasons. ... Some you know about and that's very difficult for a group of players to cope with that - and some other reasons we will talk about on another day. ... Psychologically the atmosphere was absolutely 
horrendous. It has been difficult, yes, and certainly my personal situation has contributed to that but you can never question my professionalism or commitment. (BBC, 2017)

He thereby acknowledged that the uncertainly about his own future had been a factor that had destabilized the team. Most would agree that football supporters expect that the people who play for and run their team should be dedicated to their club; it is part of their collective ILT. By hesitating over signing his new contract, he appeared uncommitted to the club and the team despite over 20 years of loyal service. The telling phrase is, 'you can never question my professionalism or commitment,' as this appears to reveal that Wenger genuinely believes that he has remained professional and committed throughout this period, something we do not dispute. This is the truth of the matter for Wenger, but the social constructionist observer would respond, 'we can and we do,' or rather, 'people could and they did.' This is perhaps the greatest insight that the social constructionist approach offers for people in the real world; it is a reminder that it doesn't matter (much) what the truth is; it matters more what people think the truth is. The socially-constructed approach to leadership explains these events and demonstrates how those involved in sport management need to consider how they might align their behaviors with the leadership expectations of key stakeholders.

There is a need to consider how assigned leaders might influence a group's collective social construction of leadership. While the social construction approach indeed has a focus on mental models of leadership, it is plausible that assigned leaders could perhaps play a significant role over time of modifying follower perceptions of what leadership means. As general definitions suggest that leadership is ultimately about 
producing change, influencing followers, and clarifying a big picture (Kotter, 1990;

Northouse, 2016), this rationale could also be applied towards influencing a collective to consider leadership in a manner that is better aligned with their own personal views and image. For example, consider a scenario where a sport federation chairperson is appointed due to her authentic and collaborative leadership style, only to find out later that this did not match the prototypical view of how leadership is perceived by the individuals she was appointed to lead. Rather than adjusting to the apparent needs of her followers (who were seeking more directive style), the approach noted above could provide a pathway for remaining true to her own principles by re-shaping how the collective, values aspects of leadership (e.g., authenticity and collaboration) which she values herself.

\section{Conclusion}

The main goal of this paper was to advocate for the increased adoption of the social construction approach to leadership in the discipline of sport management and to explore the research, teaching, and practical implications that flow from this exercise. In doing so, we have shown that the application of this paradigm helps us reinterpret our existing understanding of leadership in sport management and crucially raises implications for research, teaching, and practice. Unfortunately, we have only been able to touch upon some of the more obvious and immediate implications. There are many exciting sport management avenues to pursue in this paradigm shift, which can serve as a gateway for advanced understanding of leadership principles. 


\section{References}

Anderson, R. M., \& Funnell, M. M. (2005). Patient empowerment: reflections on the challenge of fostering the adoption of a new paradigm. Patient Education and Counseling, 57, 153-157.

Arnold, R., Fletcher, D., \& Molyneux, L. (2012). Performance leadership and management in elite sport: Recommendations, advice and suggestions from national performance directors. European Sport Management Quarterly, 12, $317-$ 336.

Ayman-Nolley, S., \& Ayman, R. (2005). Children's implicit theories of leadership. In B. Schyns, \& J. R. Meindl (Eds.), The leadership horizon series: Implicit leadership theories-Essays and explorations (pp. 227-274). Greenwich, CT: Information Age.

Bang, H. (2011). Leader-member exchange in nonprofit sport organizations. Nonprofit Management \& Leadership, 22, 85-105.

Barker, R. A. (2001). The nature of leadership. Human Relations, 54, 469-494.

Barker, R. A. (2002). On the nature of leadership. Lanham, MD: University Press of America.

Barrick, M. R., \& Mount, M. K. (1991). The big five personality dimensions and job performance: a meta $\square$ analysis. Personnel Psychology, 44, 1-26.

Baruch, Y. (1998). Leadership - Is That What We Study? Journal of Leadership \& Organizational Studies, 5, 100-124.

Bass, B. M. (1990). Bass and Stogdill's handbook of leadership. New York: Free Press. 
BBC (17 May 2017). Arsene Wenger says his future was a factor as Arsenal fail to make Champions League. Downloaded from http://www.bbc.com/sport/football/39994392 on 23 May 2017.

Billsberry, J. (2013). Teaching leadership from a social constructionist perspective. Journal of Management \& Organization, 19, 679-688.

Billsberry, J. (2016). Once learned, never forgotten: Effective leadership development with social construction as a threshold concept. Development and Learning in Organizations: An International Journal, 30, 24-26.

Blaikie, N. (2007). Approaches to social enquiry. $2^{\text {nd }}$ edition. Cambridge, UK: Polity Press.

Bligh, M. C., Kohles, J. C., \& Pillai, R. (2011). Romancing leadership: Past, present, and future. The Leadership Quarterly, 22, 1058-1077.

Calder, B. J. (1977). An attribution theory of leadership. In B. M. Staw \& G. R. Salancik (Eds.), New directions in organizational behavior (pp. 179-202). Chicago: St. Clair Press.

Chelladurai, P. (1980). Leadership in sports organizations. Canadian Journal of Applied Sport Sciences, 5, 226-231.

Chelladurai, P., \& Saleh, S. D. (1980). Dimensions of leader behavior in sports: Development of a leadership scale. Journal of Sport Psychology, 2, 34-45.

Conger, J. A., \& Kanungo, R. N. (1998). Charismatic leadership in organizations. Sage Publications.

Daft, R. L. (1999). Leadership: Theory and practice. Orlando, FL: Dryden Press. 
Day, D. V, Fleenor, J. W., Atwater, L. E., Sturm, R. E., \& Mckee, R. A. (2014).

Advances in leader and leadership development: A review of 25 years of research and theory. The Leadership Quarterly, 25, 63-82.

Defrantz, A. L. (1988). Women and leadership in sport. Journal of Physical Education, Recreation \& Dance, 59, 46-48.

De Hoogh, A. H., Den Hartog, D. N., \& Koopman, P. L. (2005). Linking the Big Five $\square$ Factors of personality to charismatic and transactional leadership; Perceived dynamic work environment as a moderator. Journal of Organizational Behavior, $26,839-865$.

Doh, J. P. (2003). Can leadership be taught? Perspectives from management educators. Academy of Management Learning and Education, 2, 54-67.

Doherty, A. J., \& Danylchuk, K. E. (1996). Transformational and transactional leadership in interuniversity athletics management. Journal of Sport Management, 10, 292309.

Eden, D., \& Leviatan, U. (1975). Implicit leadership theory as a determinant of the factor structure underlying supervisory behavior scales. Journal of Applied Psychology, $60,736-741$.

Elgar, M. A. (2016). Leader selection and leadership outcomes: Height and age in a sporting model. Leadership Quarterly, 27, 588-601.

Engle, E. M., \& Lord, R. G. (1997). Implicit theories, self-schemas, and leader-member exchange. Academy of Management Journal, 40, 988-1010.

Epitropaki, O., Sy, T., Martin, R., Tram-Quon, S., \& Topakas, A. (2013). Implicit leadership and followership theories "in the wild": Taking stock of information- 
processing approaches to leadership and followership in organizational settings. Leadership Quarterly, 24, 858-881

Epitropaki, O., Kark, R., Mainemelis, C., \& Lord, R. G. (2017). Leadership and followership identity processes: A multilevel review. Leadership Quarterly, 28, $104-129$.

Fairhurst, G. T., \& Grant, D. (2010). The social construction of leadership: A sailing guide. Management Communication Quarterly, 24, 171-210.

Ferkins, L., \& Shilbury, D. (2012). Good boards are strategic: What does that mean for sport governance? Journal of Sport Management, 26, 67-80.

Ferkins, L., \& Shilbury, D. (2015). The stakeholder dilemma in sport governance: Toward the notion of "stakeowner". Journal of Sport Management, 29, 93-108.

Ferkins, L., Shilbury, D., \& McDonald, G. (2005). The role of the board in building strategic capability: Towards an integrated model of sport governance. Sport Management Review, 8, 195-225.

Ferkins, L., Shilbury, D., \& McDonald, G. (2009). Board involvement in strategy: Advancing the governance of sport organizations. Journal of Sport Management, $23,245-277$.

Fiedler, F. E. (1964). A contingency model of leadership effectiveness. In L. Berkowitz (Ed.), Advances in experimental social psychology (pp. 149-190). New York, NY: Academic Press.

Fiedler, F. E. (1967). A theory of leadership effectiveness. New York, NY: McGraw-Hill. Fletcher, D., \& Arnold, R. (2011). A qualitative study of performance leadership and management in elite sport. Journal of Applied Sport Psychology, 23, 223-242. 
Foti, R. J., Hansbrough, T. K., Epitropaki, O., \& Coyle, P. T. (2017). Dynamic viewpoints on implicit leadership and followership theories: Approaches, findings, and future directions. The Leadership Quarterly, 28, 261-267.

Grint, K. (1997). Reading Tolstoy’s wave. In K. Grint (Ed.), Leadership: Classical, contemporary, and critical approaches (pp. 1-26). Oxford: Oxford University Press.

Grint, K. (2000). The arts of leadership. Oxford: Oxford University Press.

Grint, K. (2005). Leadership: Limits and possibilities. Basingstoke: Palgrave.

Grint, K., \& Jackson, B. (2010). Toward "socially constructive" social constructions of leadership. Management Communication Quarterly, 24, 348-355.

Harvey, M. (2006). Leadership and the human condition. In G. R. Goethals and G. L. J. Sorenson (Eds.) The quest for a general theory of leadership (pp. 39-45). Cheltenham, UK: Edward Elgar.

Hogan, R., Curphy, G. J., \& Hogan, J. (1994). What we know about leadership: Effectiveness and personality. American Psychologist, 49, 493-504.

House, R. J., \& Aditya, R. N. (1997). The social scientific study of leadership: Quo vadis? Journal of Management, 23, 409-473.

House, R. J., \& Dessler, G. (1974). The path-goal theory of leadership: Some post hoc and a priori tests. In J. G. Hunt \& L. L. Larson (Eds.) Contingency approaches to leadership (pp. 29-62). Carbondale, Il.: Southern Illinois University Press.

Hoye, R. (2004). Leader-member exchanges and board performance of voluntary sport organizations. Nonprofit Management \& Leadership, 15, 55-70. 
Iles, P., \& Preece, D. (2006). Developing leaders or developing leadership? The Academy of Chief Executives' programmes in the North East of England. Leadership, 2, 317-340.

Jackson, B., \& Parry, K. (2011). A very short, fairly interesting and reasonably cheap book about studying leadership (2 ${ }^{\text {nd }}$ edn). London: Sage.

Jones, T., Chapman, G., Cleese, J., Gilliam, T., Idle, E., \& Palin, M. (1979). Monty Python's Life of Brian. Hand Made Films.

Jowett, S., \& Chaundy, V. (2004). An investigation into the impact of coach leadership and coach-athlete relationship on group cohesion. Group Dynamics: Theory, Research, and Practice, 8, 302-311.

Judge, T. A., Bono, J. E., Ilies, R., \& Gerhardt, M. W. (2002). Personality and leadership: A qualitative and quantitative review. Journal of Applied Psychology, 87, 765-780.

Junker, N. M., Stegmann, S., Braun, S., \& Van Dick, R. (2016). The ideal and the counter-ideal follower - advancing implicit followership theories. Leadership \& Organization Development Journal, 37, 1205-1222.

Kellett, P. (1999). Organizational leadership: Lessons from professional coaches. Sport Management Review, 2, 150-171.

Kelley, H. H., \& Michela, J. L. (1980). Attribution theory and research. Annual Review of Psychology, 31, 457-501.

Kenney, R. A., Schwartz-Kenney, B. M., \& Blascovich, J. (1996). Implicit leadership theories: Defining leaders described as worthy of influence. Personality and Social Psychology Bulletin, 22, 1128-1143. 
Kihl, L. A., Leberman, S., \& Schull, V. (2010). Stakeholder constructions of leadership in intercollegiate athletics. European Sport Management Quarterly, 10, 241-275.

Kirkpatick, S. A., \& Locke, E. A. (1991). Leadership: do traits matter? The Executive, 5, 48-60.

Kotter, J. P. (2008). Force for change: How leadership differs from management. Simon and Schuster.

Kruse, E., \& Sy, T. (2011). Manipulating implicit theories by inducing affect. Academy of Management Proceedings, 1-6.

Kuhn, T. S. (1970) The structure of scientific revolutions. 2nd ed. Chicago: The University of Chicago Press.

Lewin, K., \& Lippitt, R. (1938). An experimental approach to the study of autocracy and democracy: A preliminary note. Sociometry, 1, 292-300.

Lord, R. G. (2005). Implicit leadership theory. In B. Schyns, \& J. R. Meindl (Eds.), The leadership horizon series: Implicit leadership theories-Essays and explorations (pp. ix-xiv). Greenwich, CT: Information Age.

Lord, R. G., DeVader, C. L., \& Alliger, G. M. (1986). A meta-analysis of the relation between personality traits and leadership: An application of validity generalization procedures. Journal of Applied Psychology, 71, 402-410.

Lord, R. G., \& Maher, K. J. (1993). Leadership and information processing. London: Routledge.

Lovett, D. J., \& Lowry, C. (1988). The role of gender in leadership positions in female sport programs in Texas colleges. Journal of Sport Management, 2, 106-117. 
MacLeod, A. K. (2015). Well-Being: Objectivism, Subjectivism or Sobjectivism? Journal of Happiness Studies, 16, 1073-1089.

Mann, R. D. (1959). A review of the relationships between personality and performance in small groups. Psychological Bulletin, 56, 241-270.

Marshak, R. J., \& Grant, D. (2008). Organizational discourse and new organization development practices. British Journal of Management, 19, S7-S19.

Martinko, M. J., Harvey, P., \& Douglas, S. C. (2007). The role, function, and contribution of attribution theory to leadership: A review. The Leadership Quarterly, 18, 561585.

McGregor, D. (1960). The human side of enterprise. New York, NY: McGraw-Hill.

Meindl, J. R. (1995). The romance of leadership as a follower-centric theory: A social constructionist approach. The Leadership Quarterly, 6, 329-341.

Meindl, J. R., Ehrlich, S. B., \& Dukerich, J. M. (1985). The romance of leadership. Administrative Science Quarterly, 30, 78-102.

Meisel, S. I., \& Billsberry, J. (2009). Introduction to teaching learning: Social responsibility in the management classroom. Organization Management Journal, 6, $164-165$.

Mello, J. A. (2003). Profiles in leadership: Enhancing learning through model and theory building. Journal of Management Education, 27, 344-361.

Meyer, J. H. F. (2008) Threshold concepts within the disciplines. Sense publishers.

Meyer, J. H. F. and Land, R. (2005). Threshold concepts and troublesome knowledge (2): Epistemological considerations and a conceptual framework for teaching and learning. Higher Education, 49, 373-388. 
Nichols, A. L. (2015). What do people desire in their leaders? The role of leadership level on trait desirability. Leadership \& Organization Development Journal, 37, 658671.

Northouse, P. G. (2015). Leadership: Theory and practice. London: Sage.

Offermann, L. R., Kennedy, J. K., \& Wirtz, P. W. (1994). Implicit leadership theories: Content, structure, and generalizability. The Leadership Quarterly, 5, 43-58.

Ospina, S., \& Foldy, E. (2010). Building bridges from the margins: The work of leadership in social change organizations. The Leadership Quarterly, 21, 292-307.

Parent, M.M., Beaupre, R., \& Seguin, B. (2009). Key leadership qualities for major sporting events: The case of the World Aquatics Championships. International Journal of Sport Management and Marketing, 6, 367-388.

Parent, M. M., Olver, D., \& Seguin, B. (2009). Understanding leadership in major sporting events: The case of the 2005 World Aquatics Championships. Sport Management Review, 12, 167-184.

Parris, D.L., \& Welty Peachey, J. (2013). Encouraging servant leadership: A qualitative study of how a cause-related sporting event inspires participants to serve. Leadership, 9, 486-512.

Pillai, R., \& Meindl, J. R. (1998). Context and charisma: A “meso" level examination of the relationship of organic structure, collectivism, and crisis to charismatic leadership. Journal of Management, 24, 643-671.

Sagas, M., \& Wigley, B. J. (2014). Gray area ethical leadership in the NCAA: The ethics of doing the wrong things right. Journal of Intercollegiate Sport, 7, 40-57. 
Sandberg, J. (2001). The constructions of social constructionism. In S. E. Sjo “strand, J. Sandberg \& M. Tyrstrup (Eds.), Invisible management: The social construction of leadership (pp. 28-48). London: Thomson Learning.

Schneider, R.C. (2012). Emotional intelligence: The overlooked component of sport leadership. International Journal of Sport \& Society, 3, 43-56.

Schyns, B., Gilmore, S., \& Dietz, G. (2016). What lessons can we learn from football about leadership and management? In Leadership lessons from compelling contexts (pp. 95-127). Emerald Group Publishing Limited.

Schyns, B., Kiefer, T., Kerschreiter, R., \& Tymon, A. (2011), Teaching implicit leadership theories to develop leaders and leadership: How and why it can make a difference. Academy of Management Learning \& Education, 10, 397-408.

Schyns, B., \& Meindl, J. R. (2005). Implicit leadership theories: Essays and explorations (Vol. 3rd in the Leadership Horizons Series). USA: Information Age Publishing Inc.

Schyns, B., \& Schilling, J. (2011). Implicit leadership theories: Think leader, think effective? Journal of Management Inquiry, 20, 141-150.

Shilbury, D. (2001). Examining board member roles, functions and influence: A study of Victorian sporting organizations. International Journal of Sport Management, 2, 253-281.

Shilbury, D., Ferkins, L., \& Smythe, L. (2013). Sport governance encounters: Insights from lived experiences. Sport Management Review, 16, 349-363.

Smith, A. C., \& Stewart, B. (2010). The special features of sport: A critical revisit. Sport Management Review, 13, 1-13. 
Skinner, J. \& Lizzio, A. (2011). Adolescent male perceptions of leadership in a sporting context. Leading \& Managing, 17, 98-109

Spannaus, T. W. (2012). Creating video for teachers and trainers. San Francisco, CA: Pfeiffer.

Stogdill, R. M. (1948). Personal factors associated with leadership: A survey of the literature. Journal of Psychology, 25, 35-71.

Stogdill, R. M. (1974). Handbook of leadership: A survey of theory and research. New York, NY: The Free Press.

Staurowsky, E. J. (2014). College athletes' rights in the age of the super conference: The case of the all players united campaign. Journal of Intercollegiate Sport, 7, 11-34.

Sullivan, P., Paquette, K. J., Holt, N. L., \& Bloom, G. A. (2012). The relation of coaching context and coach education to coaching efficacy and perceived leadership behaviors in youth sport. The Sport Psychologist, 26, 122-134.

Swanson, S., \& Kent, A. (2014). The complexity of leading in sport: Examining the role of domain expertise in assessing leader credibility and prototypicality. Journal of Sport Management, 28, 81-93.

Tee, E. Y. J., Paulsen, N., \& Ashkanasy, N. M. (2013). Revisiting followership through a social identity perspective: The role of collective follower emotion and action. Leadership Quarterly, 24, 902-918.

Theberge, N. (1984). Some evidence on the existence of a sexual double standard in mobility to leadership positions in sport. International Review for the Sociology of Sport, 19, 185-197. 
Toosi, N. R., \& Ambady, N. (2011). Ratings of essentialism for eight religious identities. International Journal for the Psychology of Religion, 21, 17-29.

Trichas, S., Schyns, B., Lord, R., \& Hall, R. (2016). "Facing” leaders: Facial expression and leadership perception. The Leadership Quarterly, 28, 317-333.

Uhl-Bien, M., Riggio, R. E., Lowe, K. B., \& Carsten, M. K. (2014). Followership theory: A review and research agenda. Leadership Quarterly, 25, 83-104.

Wallace, M., \& Weese, W. J. (1995). Leadership, organizational culture, and job satisfaction in Canadian YMCA organizations. Journal of Sport Management, 9, 182-193.

Walumbwa, F. O., Avolio, B. J., Gardner, W. L., Wernsing, T. S., \& Peterson, S. J. (2008). Authentic leadership: Development and validation of a theory-based measure. Journal of Management, 34, 89-126.

Weese, W. J. (1995). Leadership and organizational culture: An investigation of Big Ten and Mid-American Conference Campus Recreation Administrations. Journal of Sport Management, 9, 119-134.

Welty Peachey, J. W., Damon, Z. J., Zhou, Y., \& Burton, L. J. (2015). Forty years of leadership research in sport management: A review, synthesis, and conceptual framework. Journal of Sport Management, 29, 570-587.

Welty Peachey, J., \& Burton, L. (2017). Servant leadership in sport for development and peace: A way forward. Quest, 69, 125-139.

Whiteley, P., Sy, T., \& Johnson, S. K. (2012). Leaders' conceptions of followers: Implications for naturally occurring Pygmalion effects. Leadership Quarterly, 23, $822-834$. 
Wood, M. (2005). The fallacy of misplaced leadership. Journal of Management Studies, $42,1101-1121$.

Wright, A. L. \& Gilmore, A. (2011), Threshold concepts and conceptions: student learning in introductory management courses. Journal of Management Education, $36,614-635$.

Yukl, G. (1998). Leadership in organizations. Upper Saddle River, NJ: Prentice Hall.

Yukl, G., \& Van Fleet, D. D. (1992). Theory and research on leadership in organizations.

In M. D. Dunnette \& L. M. Hough (Eds.), Handbook of industrial and organizational psychology (Vol. 3, pp. 147-197). Palo Alto, CA: Consulting Psychologists Press. 